\title{
MARGINALIJE UZ (MEĐUNARODNU) NADLEŽNOST U PREDMETIMA O RODITELJSKOJ SKRBI ${ }^{* *}$
}

Sažetak: $\quad$ Kriterije koje je Uredba Vijeća (EZ) broj 2201/2003 o nadležnosti i priznanju i ovrsi odluka u bračnim predmetima i predmetima roditeljske odgovornosti, kojom se ukida Uredba (EZ) broj 1347/2000 (u daljnjem tekstu: Uredba) prihvatila $u$ vezi s uređenjem (međunarodne) nadležnosti u predmetima o roditeljskoj odgovornosti odstupaju od kriterija kojima je uređeno to pitanje u domaćem pravu. Ponajprije se to odstupanje odnosi na situacije u kojima se uz brakorazvodni postupak adhezijski odlučuje o pitanjima roditeljske skrbi. Specifičnost je tih postupaka u domaćem pravu i u poticanju mirnog rješavanja obiteljskopravnih sporova, a koji mehanizmi bi trebali prethoditi pokretanju postupka pred sudom, čime se otvara i pitanje određenja "trenutka pokretanja postupka pred sudom" pri ocjeni nadležnosti uspostavljene Uredbom.

Cilj je ovoga rada analizirati pravila o (međunarodnoj) nadležnosti u predmetima o roditeljskoj skrbi o kojima se adhezijski odlučuje uz brakorazvodni postupak. Pritom se nastoje raspraviti određena implementacijsko-praktična pitanja koja se javljaju u primjeni Uredbe. U vrijeme pisanja rada objavljen je Prijedlog revizije Uredbe kojim su učinjene određene intervencije i u sustav nadležnosti u predmetima o roditeljskoj odgovornosti, a čije se procesnopravne posljedice također nastoje analizirati u radu.

Ključne riječi: (adhezijski) spor o roditeljskoj skrbi, nadležnost, mirno rješavanje spora, briselska Uredba II bis, postupak

\footnotetext{
Dr. sc. Slađana Aras Kramar, docentica na Katedri za građansko procesno pravo Pravnog fakulteta Sveučilišta u Zagrebu. Trg maršala Tita 14, 10000 Zagreb, Republika Hrvatska. Adresa e-pošte: saras@pravo.hr.

** Ovaj rad je sufinancirala Hrvatska zaklada za znanost projektom broj 6988.
} 


\section{UVOD}

Jedno je od obilježja hrvatskog obiteljskog postupovnog prava naglašena primjena načela oficijelnosti koja se u predmetima o roditeljskoj skrbi te uzdržavanju djeteta odražava (i) uz pomoć pravila prema kojima je sud dužan po službenoj dužnosti odlučiti o tome s kojim će roditeljem dijete stanovati, o ostvarivanju roditeljske skrbi i osobnih odnosa djeteta s drugim roditeljem te uzdržavanju djeteta u presudi kojom se brak razvodi (čl. 56., čl. 413. st. 1. t. 1. Obiteljskog zakona ${ }^{1}$ ). Štoviše, ako bi nakon pokretanja (samostalnog) postupka o roditeljskoj skrbi bio pokrenut postupak radi razvoda braka, sud bi prema ObZ-u 15 bio dužan po službenoj dužnosti spojiti taj postupak s postupkom radi razvoda braka (čl. 412. ObZ-a 15). Upravo je stoga pokretanje brakorazvodnog postupka pred sudom učinjeno ovisnim o prethodnom pokretanju postupka obveznog savjetovanja (te eventualno prvog sastanka obiteljske medijacije), ${ }^{2}$ a koji postupci imaju za cilj sporazumno rješavanje pitanja koja se odnose na djecu. ${ }^{3}$

Pristupanje Republike Hrvatske Europskoj uniji (u daljnjem tekstu: EU), na području (obiteljskog) pravosuđenja, ujedno je značilo i izravnu primjenu izvora sekundarnog europskog prava, ponajprije Uredbe Vijeća (EZ) broj 2201/2003 o nadležnosti i priznanju i ovrsi odluka u bračnim predmetima i predmetima roditeljske odgovornosti, kojom se ukida Uredba (EZ) broj 1347/20004, 5 . BU II bis kao akt sekundarnog europskog prava propisuje pravila o izravnoj nadležnosti u (bračnim predmetima i) predmetima o roditeljskoj odgovornosti. Kriterije koje je BU II bis prihvatila u vezi s uređenjem nadležnosti u predmetima o roditeljskoj odgovornosti odstupaju od kriterija kojim je uređeno pitanje (međunarodne i mjesne) nadležnosti hrvatskim Zakonom o rješavanju sukoba zakona s propisima drugih zemalja u određenim odnosima ${ }^{6}$ te ObZ-om 15. To se odstupanje, prije svega, odnosi na situacije u kojima se uz brakorazvodni postupak (adhezijski, pridruženo) odlučuje o pitanjima roditeljske skrbi (te uzdržavanja djeteta). ${ }^{7}$

1 Obiteljski zakon iz 2015., Narodne novine Republike Hrvatske, broj 103/2015 (u daljnjem tekstu: ObZ 15).

2 Vidjeti čl. 54., čl. 379., čl. 456.-458. ObZ-a 15.

3 Vidjeti 321. st. 1., čl. 324., čl. 325. ObZ-a 15. Vidjeti Obrazloženje Konačnog prijedloga Obiteljskog zakona iz 2015., Zagreb, rujan 2015., URL=http://www.sabor.hr/konacni-prijedlog-obiteljskog-zakona-drugo-cit0001, str. 174, 266, 268.-269. Pristupljeno 28. prosinca 2016.

4 Council Regulation (EC) No 2201/2003 of 27 November 2003 concerning jurisdiction and the recognition and enforcement of judgments in matrimonial matters and the matters of parental responsibility, repealing Regulation (EC) No 1347/2000, Official Journal of the European Union, broj L 338, str. 1.- 29. U daljnjem tekstu: BU II bis; Uredba; Briselska uredba II bis. Objavljeni prijevod na hrvatski jezik v. na: URL=http://eur-lex.europa.eu/legal-content/HR/TXT/?uri=celex\%3A32003R2201. Pristupljeno 21. studenoga 2016.

5 BU II bis u cijelosti obvezuje te se izravno i neposredno primjenjuje u svim državama članicama EU-a, osim u Danskoj (čl. 72. st. 3. BU-a II bis). BU II bis stupila je na snagu 1. kolovoza 2004., a primjenjuje se od 1. ožujka 2005. s iznimkom čl. 67., čl. 68., čl. 69. i čl. 70. BU-a II bis koji se primjenjuju od 1. kolovoza 2004. (čl. 72. st. 1. i 2. BU-a II bis). Vidjeti Praktični priručnik za primjenu Uredbe Bruxelles II.a, Europska komisija, Bruxelles, 2014. URL=http://ec.europa.eu/justice/civil/files/brussels-ii-practice-guidehr.pdf, str. 5. Pristupljeno 25. studenoga 2016.

6 Zakon o rješavanju sukoba zakona s propisima drugih zemalja u određenim odnosima, Narodne novine Republike Hrvatske, broj 53/1991, 88/2001 (u daljnjem tekstu: ZRSZ). U vrijeme pisanja rada bio je objavljen u sklopu e-savjetovanja Nacrt prijedloga Zakona o međunarodnom privatnom pravu, od 10. studenoga 2016. do 25. studenoga 2016. URL=https://esavjetovanja.gov.hr/ ECon/MainScreen?entityId=4310. Pristupljeno 28. prosinca 2016. U daljnjem tekstu: NP ZMPP.

7 Područje uzdržavanja uređeno je Uredbom Vijeća (EZ) broj 4/2009 o nadležnosti, mjerodavnom pravu, priznanju i ovrsi odluka te suradnji u stvarima uzdržavanja (Council Regulation (EC) No 4/2009 of 18 December 2008 on jurisdiction, applicable law, recognition and enforcement of decisions and cooperation in matters relating to maintenance obligations), Official Journal of 
U vrijeme pisanja rada objavljen je Prijedlog Uredbe Vijeća o nadležnosti, priznanju i ovrsi odluka u bračnim predmetima i predmetima o roditeljskoj odgovornosti, i o međunarodnoj otmici djece (revizija) ${ }^{8}$ u kojem ponajprije nije u središtu interesa sustav nadležnosti uspostavljen BU-om II bis. ${ }^{9}$ Unatoč tomu PBU-om II bis učinjene su određene intervencije u sustav nadležnosti u predmetima o roditeljskoj odgovornosti koje imaju značajnije procesnopravne posljedice u vezi s primjenom načela perpetuatio fori te prorogacije nadležnosti sudu koji odlučuje u bračnom sporu, a o kojima će biti riječi u ovom radu.

Cilj je ovoga rada analizirati pravila o (međunarodnoj) nadležnosti u predmetima o roditeljskoj skrbi o kojima se odlučuje u povodu brakorazvodnog postupka te raspraviti određena implementacijsko-praktična pitanja koja se pritom javljaju u primjeni BU-a II bis. U tom kontekstu, u radu je sadržana analiza općeg te određenih posebnih pravila o nadležnosti BU-a II bis u predmetima o roditeljskoj odgovornosti o kojima se odlučuje u povodu brakorazvodnog postupka, uzimajući u obzir i izmjene koje su predviđene u tom sustavu PBU-om II bis. Potom se raspravlja o (atrakcijskoj) nadležnosti u (adhezijskim) sporovima o roditeljskoj skrbi prema ZRSZ-u te ObZ-u 15. U četvrtom i petom dijelu rada analiziraju se određena implementacijsko-praktična pitanja primjene odredaba o izravnoj nadležnosti BU-a II bis u predmetima o roditeljskoj skrbi u Hrvatskoj te se pokušavaju naznačiti mogući pravci za iznalaženje rješenja.

Predmet su analize u radu sporovi o roditeljskoj skrbi do kojih dolazi zbog razvoda braka roditelja, a koji se rješavaju pridruženo, adhezijski uz spor radi razvoda braka kao glavni spor. Prema terminologiji ObZ-a 15, riječ je o sporovima s kojim će roditeljem dijete stanovati, o ostvarivanju roditeljske skrbi te osobnih odnosa djeteta s drugim roditeljem (čl. 408., čl. 412., čl. 413. st. 1. ObZ-a 15). U Briselskoj uredbi II bis navedeni sporovi označavaju se kao predmeti o roditeljskoj odgovornosti (v. infra ad 2.1.). Iako je koncept "roditeljska odgovornost" Briselske uredbe II bis znatno širi od "roditeljske skrbi” kako je ona definirana ObZ-om 15, u radu se ti pojmovi koriste kao istoznačnice ako iz konteksta ne proizlazi drukčije.

\section{NADLEŽNOST U PREDMETIMA O RODITELJSKOJ SKRBI PREMA BRISELSKOJ UREDBI II BIS}

\subsection{OPĆENITO}

Ratione materiae, BU II bis primjenjuje se, bez obzira na prirodu suda pred kojim se postupak vodi, na bračne predmete te predmete o roditeljskoj odgovornosti, preciznije, predmete o

the European Union, broj L 7, str. 1.-79. U daljnjem tekstu: Uredba o uzdržavanju. Rad ne obuhvaća analizu pravila o (izravnoj) nadležnosti Uredbe o uzdržavanju s obzirom na to da bi to zahtijevalo posebnu studiju.

8 Proposal for a Council Regulation on jurisdiction, the recognition and enforcement of decision in matrimonial matters and the matters of parental responsibility, and on international child abduction (recast), $\operatorname{COM}(2016) 411$ final, European Commission, Brussels, 30. lipnja 2016., URL=https://ec.europa.eu/transparency /regdoc/rep/1/2016/EN/1-2016-411-EN-F1-1.PDF. Pristupljeno 21. studenoga 2016. U daljnjem tekstu: PBU II bis.

9 U Obrazloženju PBU-a II bis istaknuto je šest područja u kojima se javljaju problemi u primjeni Uredbe u predmetima o roditeljskoj odgovornosti te u kojima bi se revizijom Uredbe nastojali postići pozitivni pomaci. O tome v. Explanatory memorandum, u: Proposal for a Council Regulation on jurisdiction, the recognition and enforcement of decision in matrimonial matters and the matters of parental responsibility, and on international child abduction (recast), op. cit. u bilj. 8, str. 3.-5., 7.-8., 14.-17. Usp. de Boer, Th.M., What we should not expect from a recast of the Brussels IIbis Regulation, URL=http://www.nipr-online.eu/upload/ documents/20150331T124932-NIPR\%202015-1-De\%20Boer-sample\%20copy.pdf, str. 10.-19. Pristupljeno 20. prosinca 2016. 
dodjeljivanju, ostvarivanju, prijenosu, ograničenju ili oduzimanju roditeljske odgovornosti (čl. 1. st. 1. t. b) BU II bis). Pritom BU II bis propisuje autonomne definicije pojmova "sud" te "roditeljska odgovornost". Pojam "sud” podrazumijeva sva tijela u državama članicama nadležna za predmete iz polja primjene BU-a II bis (čl. 2. st. 1. BU-a II bis).

Tko bi se smatrao "tijelom" u smislu određenja pojma "sud" u kontekstu primjene BU-a II bis (djelomično te neizravno) ukazuje praksa Suda EU-a. U predmetu C-523/07, A, [2009] ECR I-2805 od 2. travnja 2009., Sud je zauzeo shvaćanje da su i odluke kojima se nalaže trenutačno preuzimanje skrbi i smještaj djeteta izvan vlastite obitelji, a koje su odluke donesene u okviru javnopravne zaštite djece obuhvaćene pojmom "građanske stvari” u smislu primjene BU-a II bis. ${ }^{10}$ Iz toga bi se shvaćanja moglo ujedno zaključiti da "tijelo" nadležno za predmete iz polja primjene BU-a II bis ne bi uvijek morao biti "sud” u smislu domaćeg prava. Da bi se pod pojam "sud" trebala u određenim slučajevima podvesti i upravna tijela u kontekstu primjene BU-a II bis, ukazuje PBU II bis. PBU-om II bis prihvaćena je izmjena autonomne definicije pojma "sud" tako da se sada propisuje definicija pojma "tijelo" (authority), a koje se definira kao svako sudsko ili upravno tijelo države članice koje je nadležno za predmete iz polja primjene BU-a II bis (pred. čl. 2. t. 1. PBU-a II bis). ${ }^{11},{ }^{12}$

Pod pojmom “roditeljska odgovornost" BU II bis podrazumijeva sva prava i obveze u vezi s osobom ili imovinom djeteta koja su fizičkoj ili pravnoj osobi dana odlukom, ${ }^{13}$ zakonom ili sporazumom koji proizvodi pravne učinke, uključujući i pravo na roditeljsku skrb te pravo na ostvarivanje osobnih odnosa s djetetom (čl. 2. st. 7. BU-a II bis). ${ }^{14}$ BU II bis, međutim, ne određuje tko se smatra djetetom za potrebe njezine primjene. ${ }^{15} \mathrm{~S}$ druge strane, PBU-om II bis u čl. 2. izrijekom je propisana autonomna definicija pojma "dijete". Tako se BU II bis primjenjuje na svaku osobu koja nije navršila 18 godina života (pred. čl. 2. t. 7. PBU-a II bis). ${ }^{16}$

10 Vidjeti Praktični priručnik za primjenu Uredbe Bruxelles II.a, op. cit. u bilj. 5, str. 20.-22.

11 Inače samo nacionalni "sud" može pokrenuti postupak za prethodnim tumačenjem prava EU-a te je koncept "suda" europski, odnosno razvijao se u praksi Suda. Vidjeti Ćapeta, T., Sudski sustav Europske unije i njegov utjecaj na procesna prava država članica, u: Garašić, J. (ur.), Europsko građansko procesno pravo - izabrane teme, Narodne novine, Zagreb, 2013., str. 41.-42.; za sudsku praksu, odnosno elemente koje bi trebalo uzeti u obzir kod ocjene je li riječ o "sudu” v. Craig, P., de Búrca, G., EU Law, Text, Cases, and Materials, 6th ed., Oxford University Press, Oxford, 2015., str. 466.-468; Ćapeta, T., Sudovi Europske unije: Nacionalni sudovi kao europski sudovi, Institut za međunarodne odnose, Zagreb, 2002., str. 199.-202.

12 U odredbi o polju primjene BU-a II bis predviđeno je da se pojam "sud ili tribunal" (court or tribunal) zamijeni pojmom "sudsko ili upravno tijelo" (judicial or administrative authority) (pred. čl. 1. st. 1. t. b) BU II bis.

13 PBU-om II bis došlo je do renumeracije tako da je pojam "roditeljska odgovornost" definiran u odredbi čl. 2. t. 8. Uredbe. Osim toga, umjesto termina "presuda" u predloženoj definiciji koristi se termin "odluka" uvažavajući da se o roditeljskoj skrbi donose i druge vrste odluka osim presuda.

14 BU II bis dodatno pojašnjava pojam "roditeljska odgovornost" na način da primjerice propisuje na što se mogu odnositi predmeti o roditeljskoj odgovornosti (čl. 1. st. 2. BU-a II bis). Uz to, BU II bis izrijekom, taksativno propisuje na koje se predmete ne odnosi (čl. 1. st. 3. BU-a II bis).

15 Za određenje pojma "dijete" u kontekstu primjene Uredbe upućuje se na nacionalno pravo države članice. Nademleinsky, M., Neumayr, M., Internationales Familienrecht, Facultas Verlags- und Buchhandels, Wien, 2007, str. 140.-141. U pojedinim državama članicama EU-a različito je određen pojam djeteta. Vidjeti Study on the assessment of the Regulation (EC) No 2201/2003 and the policy options for its amendment; Final report; Evaluation, European Commission, Directorate-General for Justice and Consumers, Brussels, May 2015, URL=http://ec.europa.eu/justice/civil/files/bxl_iia_final_report_evaluation.pdf, str. 8. Pristupljeno 15. prosinca 2016.; Study on the assessment of the Regulation (EC) No 2201/2003 and the policy options for its amendment; Final report; Analytical Annexes, European Commission, Directorate-General for Justice and Consumers, Brussels, May 2015, URL=http:// ec.europa.eu/justice/civil/files/bxl-iia-final-report-analtical-annexes.pdf, str. 123. Pristupljeno 15. prosinca 2016. 
U BU-u II bis propisana su pravila o nadležnosti (poglavlje II.), priznanju i ovrsi (poglavlje III.) te suradnji između središnjih tijela (poglavlje IV.) u predmetima o roditeljskoj odgovornosti. ${ }^{17}$ Važno je istaknuti da su odredbe o nadležnosti u predmetima o roditeljskoj odgovornosti oblikovane tako da štite najbolje interese djeteta, a to se nastojalo postići kroz prihvaćanje kriterija (teritorijalne) blizine suda i djeteta kao općeg pri zasnivanju nadležnosti suda u tim predmetima (t. 12. (14.) Preambule (P)BU-a II bis). Uz odredbu o općoj nadležnosti (čl. 8. st. 1. BU-a II bis), BU II bis propisuje i posebne nadležnosti: nadležnost tijela prijašnjeg uobičajenog boravišta djeteta (čl. 9.), nadležnost u slučaju otmice djeteta (čl. 10., čl. 11.), prorogaciju nadležnosti (čl. 12.), nadležnost utemeljenu na nazočnosti djeteta (čl. 13.), supsidijarnu ili rezidualnu nadležnost (čl. 14.), mogućnost ustupanja predmeta sudu države članice koji je u boljoj poziciji da raspravi i odluči o predmetu (čl. 15.) te nadležnost u hitnim slučajevima za određivanje privremenih mjera, odnosno mjera osiguranja (čl. 20.). ${ }^{18}$

U nastavku rada analizirat će se odredbe BU-a II bis o općoj nadležnosti te o posebnim nadležnostima u predmetima o roditeljskoj odgovornosti o kojima se odlučuje adhezijski uz bračni spor i to o prorogaciji nadležnosti te ustupanju predmeta sudu države članice koji je u boljoj poziciji da raspravi i odluči o predmetu.

\subsection{NADLEŽNOST U PREDMETIMA O RODITELJSKOJ ODGOVORNOSTI}

\subsubsection{Opća međunarodna nadležnost}

Prema općem pravilu u predmetu o roditeljskoj odgovornosti nadležan je sud države članice u kojoj dijete ima uobičajeno boravište u trenutku pokretanja postupka (čl. 8. st. 1. BU-a II $\left.b i s^{19}\right)$. U PBU-u II bis umjesto pojma "sud" koristi se pojam “tijelo", uzimajući u obzir mogućnost da prema BU-u II bis postupaju ne samo sudovi, nego i upravna tijela. Osim toga, u PBU-u II bis predviđeno je i brisanje dijela odredbe kojom se propisuje trenutak "pokretanja sudskog postupka" kao trenutak s obzirom na koji se ocjenjuje pitanje nadležnosti suda, a što je posljedica napuštanja pravila o ustaljivanju nadležnosti (perpetuatio fori). Ako PBU II bis stupi na snagu, otvoreno je pitanje s obzirom na koji trenutak će se ocjenjivati nadležnost tijela. Čini se da bi to bio trenutak donošenja (meritorne) odluke (arg. ex čl. 7. st. 1. PBU-a II bis).

Pojam "uobičajeno boravište" nije definiran BU-om II bis. Sud EU-a u svojim odlukama postavio je smjernice koje bi trebale služiti tijelima primjene BU-a II bis u određivanju gdje se nalazi uobičajeno boravište djeteta. ${ }^{20}$ Upravo tumačenje pojma "uobičajeno boravište", od-

17 PBU-om II bis odredbe o otmici djeteta izdvojene su u posebno poglavlje tako da je nakon poglavlja II. o nadležnosti propisano posebno poglavlje III. o otmici djeteta, dok je priznanje te izvršenje odluka propisano u poglavlju IV. BU-a II bis.

18 PBU-om II bis propisuje se renumeracija članaka koji sadrže odredbe o nadležnosti u predmetima o roditeljskoj odgovornosti te izmjene naslova iznad pojedinih članaka, kao i premještanje odredbe o nadležnosti za određivanje privremenih mjera, odnosno mjera osiguranja u hitnim slučajevima iz poglavlja II. dijela III. (čl. 20. BU-a II bis) u poglavlje II. dio II. (pred. čl. 12. PBU-a II bis).

19 PBU-om II bis izvršena je renumeracija članaka tako da je opća nadležnost u predmetima o roditeljskoj odgovornosti propisana u čl. 7. st. 1. Uredbe.

20 Vidjeti predmet C-523/07, A, [2009] ECR I-2805 od 2. travnja 2009., dostupna na: URL=http://curia.europa.eu/juris/ document/document.jsf?text=\&docid=73639\&pageIndex=0\&doclang=EN\&mode=lst\&dir=\&occ=first\&part=1\&cid=814531. Pristupljeno 3. ožujka 2017. Predmet C-497/10 PPU, Mercredi v. Chaffea, [2010] ECR I-14309 od 22. prosinca 2010., dostupna na: URL= http://curia.europa.eu/juris/ document/document.jsf?text=\&docid=83470\&pageIndex=0\&doclang=en\&mode=lst\& 
nosno ocjena ima li se određeno mjesto smatrati uobičajenim boravištem predstavlja velike teškoće u praksi nacionalnih sudova država članica. ${ }^{21}$ Iako je Sud EU-a uspostavio smjernice prema kojima bi se trebalo prosuđivati uobičajeno boravište, Sud nije izrijekom odredio pojam uobičajenog boravišta taksativnim navođenjem njegovih konstitutivnih elemenata. ${ }^{22}$ Unatoč iznesenim kritikama i dvojbama u vezi s određivanjem pojma uobičajenog boravišta pri evaluaciji dosadašnje primjene BU-a II bis, ni objavljeni PBU II bis ne sadrži definiciju pojma uobičajenog boravišta. ${ }^{23}$

Ako bi došlo do promjene uobičajenog boravišta djeteta iz jedne države članice u drugu državu članicu nakon pokretanja postupka pred sudom nadležnim prema BU-u II bis, ta okolnost, de lege lata, u načelu ne bi utjecala na zasnovanu nadležnost suda prijašnjeg uobičajenog boravišta djeteta (pravilo o perpetuatio fori). ${ }^{24}$ Upravo je primjena pravila o ustaljivanju nadležnosti bila naznačena kao dvojbena u primjeni BU-a II bis jer da je dovodila do praktičnih teškoća u slučaju kad se dijete preselilo, a postupak se morao nastaviti pred sudom države članice u kojoj dijete više nije živjelo. Osim toga, istaknuto je da je suprotno načelo usvojeno u Haškoj konvenciji o nadležnosti, mjerodavnom pravu, priznanju, ovrsi i suradnji u odnosu na roditeljsku skrb i mjere za zaštitu djece iz 1996. godine, a koja je na snazi u svim državama članicama. ${ }^{25}$

Prema PBU-u II bis, ako se dijete zakonito preseli iz jedne države članice u drugu državu članicu i u toj državi članici stekne uobičajeno boravište, bit će nadležna tijela države članice novog uobičajenog boravišta (pred. čl. 7. st. 1. PBU-a II bis). U pred. t. 15. Preambule PBU-a II bis istaknuto je da bi u tom slučaju - zakonitog preseljenja djeteta te posljedično promjene uobičajenog boravišta u drugu državu članicu - nadležnost trebala "pratiti” dijete kako bi se održalo načelo (teritorijalne) blizine nadležnog suda te djeteta. To bi vrijedilo ne samo u slučajevima gdje postupak još nije pokrenut, nego i u slučajevima gdje je postupak u tijeku. Za postupke koji su u tijeku otvorena je mogućnost da se stranke sporazume "u interesu učinkovitosti postupka" (in the interests of the efficiency) da se postupak nastavi pred sudom države članice pred kojim je pokrenut do donošenja konačne odluke ako bi to bilo u najboljem interesu djeteta (pred. t. 15. Preambule PBU-a II bis).

Autorici se čini da odredba pred. čl. 7. st. 1. PBU-a II bis kojom se odstupa od načela perpetuatio fori otvara put mogućim zloupotrebama te odugovlačenju postupka. Treba primijetiti da je mogućnost da sud pred kojim je pokrenut postupak nastavi postupati u konkretnom predmetu o roditeljskoj odgovornosti unatoč preseljenju djeteta te stjecanja novog uobičajenog boravišta u drugoj državi članici vezana uz sporazum roditelja. Jedan bi roditelj, i to onaj koji se preselio s djetetom u drugu državu članicu, jednostavno mogao uskratiti suglasnost, odnosno

dir=\&occ=first\&part=1\&cid=814531. Pristupljeno 3. ožujka 2017. Praktični priručnik za primjenu Uredbe Bruxelles II.a, op. cit. u bilj. 5, str. 25.-27.

21 Analytical Annexes, op. cit. u bilj. 15, str. 25.-26.; Final Evaluation Report, op. cit. u bilj. 15, str. 41.- 43.

22 Analytical Annexes, op. cit. u bilj. 15, str. 26.

23 Ibid.

24 Tako Praktični priručnik za primjenu Uredbe Bruxelles II.a, op. cit. u bilj. 5, str. 27. Nademleinsky, Neumayr, op. cit. u bilj. 15, str. 149.

25 Haška konvencija o nadležnosti, mjerodavnom pravu, priznanju, ovrsi i suradnji u odnosu na roditeljsku skrb i mjere za zaštitu djece iz 1996., Narodne novine, Međunarodni ugovori, broj 5/2009. Vidjeti Analytical Annexes, op. cit. u bilj. 15, str. 29.; Final Evaluation Report, op. cit. u bilj. 15, str. 15. De Boer, op. cit. u bilj. 9, str. 15.-18. 
odbiti mogućnost zaključenja sporazuma o nadležnosti. Stoga bi roditelj mogao preseljenjem s djetetom u drugu državu članicu isprovocirati promjenu nadležnosti suda, pa i onda kad je sudski postupak u poodmakloj fazi. Upitno je također kako će sud pred kojim je postupak u tijeku postupiti u slučaju preseljenja djeteta te promjene uobičajenog boravišta u drugu državu članicu. Naime, hoće li odmah donijeti odluku u kojoj će se oglasiti nenadležnim u korist nadležnosti suda druge države članice na čijem je području dijete steklo novo uobičajeno boravište ili bi trebao pričekati izjašnjavanje stranaka u vezi s mogućnosti sporazuma o nadležnosti te prorogacije nadležnosti toga suda? Ako bi se prihvatilo potonje shvaćanje, do kojeg bi trenutka trebalo čekati da se stranke izjasne u vezi s mogućnosti sporazuma o prorogaciji nadležnosti? Na praksi Suda EU-a je da odgovori na naznačena pitanja, naravno, ako uopće odredba pred. čl. 7. st. 1. PBU-a II bis stupi na snagu. Osim toga, treba istaknuti da BU II bis, de lege lata, ima već dovoljno mehanizama da odgovori (potencijalnim) problemima koje bi mogla izazvati primjena pravila o ustaljivanju nadležnosti zbog preseljenja djeteta. ${ }^{26}$

Sve bi stoga sporove o tome s kojim će roditeljem dijete stanovati, o načinu ostvarivanja roditeljske skrbi te osobnih odnosa (a koji se pojavljuju zbog spora radi razvoda braka roditelja) u načelu trebalo rješavati u državi članici na čijem području dijete ima uobičajeno boravište (u trenutku pokretanja postupka) (arg. ex čl. 8. st. 1. BU-a II bis). Pritom ne mora biti riječ o sudu države članice pred kojim se u konkretnom predmetu raspravlja o sporu radi razvoda braka. ${ }^{27}$ Propisana je mogućnost, međutim, sporazuma o nadležnosti u predmetima o roditeljskoj odgovornosti te prorogacija nadležnosti sudu države članice u kojoj je pokrenut postupak radi razvoda braka (čl. 12. BU-a II bis). Bilo bi moguće i da sud jedne države članice ustupi predmet o roditeljskoj odgovornosti sudu druge države članice koji je u boljoj poziciji da raspravi i odluči o predmetu (a pred kojim je ujedno pokrenut spor radi razvoda braka prema BU-u II bis) (čl. 15. BU-a II bis).

\subsubsection{Posebne međunarodne nadležnosti}

\subsubsection{Prorogacija nadležnosti}

Različito od domaćeg prava, u predmetima o roditeljskoj odgovornosti BU II bis izrijekom dopušta sporazume o nadležnosti. Prema Uredbi, razlikuje se među prorogacijom nadležnosti u predmetima o roditeljskoj odgovornosti ako je bračni spor u tijeku te prorogacijom nadležnosti u predmetima o roditeljskoj odgovornosti u drugim slučajevima ako dijete ima "bitnu vezu" s tom državom članicom.

Uzimajući u obzir temu rada, u nastavku će se analizirati te raspraviti pravila BU-a II bis o prorogaciji nadležnosti u predmetima o roditeljskoj odgovornosti u slučaju ako je u tijeku bračni spor, a koja pravila su izmijenjena i dopunjena u objavljenom PBU-u II bis.

Sudovi države članice nadležni prema odredbama o općoj nadležnosti u bračnom sporu (čl. 3. BU-a II bis) nadležni su i za sve predmete o roditeljskoj odgovornosti koji su povezani s takvim zahtjevom ako su kumulativno ispunjeni sljedeći uvjeti:

26 To se ponajprije odnosi na ustupanje predmeta drugoj državi članici koja je u boljoj poziciji da raspravi o predmetu (v. infra ad 2.2.2.2). O raspravama oko (ne)primjene pravila perpetuatio fori v. Analytical Annexes, op. cit. u bilj. 15, str. 29.-30. De Boer, op. cit. u bilj. 9, str. 15.-18. 
(a) barem jedan od bračnih drugova ima roditeljsku odgovornost u odnosu na dijete

(b) bračni drugovi i nositelji roditeljske odgovornosti izričito su ili na drugi nedvojbeni način prihvatili nadležnost sudova u trenutku pokretanja postupka pred sudom te

(c) ako je to u najboljem interesu djeteta (čl. 12. st. 1. BU II bis).

Tako ustanovljena nadležnost suda u predmetima o roditeljskoj odgovornosti trebala bi postojati sve dok sudska odluka kojom se prihvaća ili odbija zahtjev za razvod, rastavu ili poništaj braka postane konačna (final) ili u onim slučajevima kada postupci o roditeljskoj odgovornosti još traju u navedenom trenutku, čim odluka u tim postupcima postane konačna (final), odnosno čim se ti postupci okončaju zbog nekog drugog razloga, npr., povlačenjem tužbe (čl. 12. st. 2. BU-a II bis).

Treba primijetiti da do zasnivanja nadležnosti na temelju prorogacijskog kriterija uopće neće doći - unatoč potrebnim suglasnostima - ako to ne bi bilo u najboljem interesu djeteta. ${ }^{28}$ Iz toga proizlazi da bi sud države članice pred kojim je pokrenut postupak u bračnom sporu trebao provesti incidentalni postupak kako bi provjerio bi li izričito ili prešutno postignuti sporazum o nadležnosti bio u skladu s najboljim interesom djeteta, odnosno postoji li uopće takav sporazum roditelja i nositelja roditeljske odgovornosti. ${ }^{29}$ Osim toga, suglasnost za prorogaciju nadležnosti ne traži se samo od bračnih drugova, stranka u pokrenutom postupku u bračnom sporu, nego i od trećih osoba ili tijela ako oni ostvaruju roditeljsku odgovornost u odnosu na dijete. To potonje moglo bi biti problematično s obzirom na zahtjev da sporazum o nadležnosti - izričiti ili prešutni - u predmetima o roditeljskoj odgovornosti mora postojati u trenutku pokretanja postupka u bračnom sporu. ${ }^{30}$ Otvoreno je pitanje na koji bi način uopće treće osobe (ili tijela) koje su nositelji roditeljske odgovornosti u odnosu na dijete, a koje nisu stranke postupka u bračnom sporu mogle iskazati svoju suglasnost da sud države članice pred kojim je pokrenut postupak u bračnom sporu bude nadležan i u predmetima o roditeljskoj odgovornosti, i to u samom trenutku pokretanja postupka u bračnom sporu.

PBU-om II bis, osim što je izvršena renumeracija članaka te je čl. 12. postao čl. 10. Uredbe, izmijenjen je i naslov iznad čl. 12. BU-a II bis tako da bi on sada trebao glasiti "Izbor suda za adhezijske i samostalne postupke" (Choice of court for ancillary and autonomous proceedings). Uz terminološke intervencije, u pred. čl. 10. st. 1. PBU-a II bis izrijekom je propisano da bračni drugovi i nositelji roditeljske odgovornosti izričito ili na drugi nedvojbeni način trebaju prihvatiti nadležnost najkasnije u trenutku pokretanja postupka pred sudom ili pak tijekom tog postupka ako to pravo te države članice propisuje (pred. čl. 10. st. 1. (b) PBU-a II bis). Pritom, ako stranke (adhezijskog) postupka o roditeljskoj odgovornosti prihvate nadležnost suda tijekom postupka u bračnom sporu, sud treba o sporazumu stranaka sastaviti zapisnik u skladu s lex fori (pred. čl. 10. st. 5. PBU-a II bis).

Pri evaluaciji primjene BU-a II bis, istaknuto je da učestalost prorogacije nadležnosti sudu države članice pred kojim je pokrenut bračni spor ovisi i o zakonodavnom okviru odnosne

\footnotetext{
28 BU II bis sadrži predmnjevu kada će se smatrati da je prorogirana nadležnost u interesu djeteta (v. čl. 12. st. 4. BU-a II bis).

29 Usp. Analytical Annexes, op. cit. u bilj. 15, str. 31.-32.

30 Usp. ibid., str. 32.
} 
države članice, posebice nacionalnim procesnim pravilima koja omogućavaju da se u istom postupku raspravi bračni spor i spor o roditeljskoj skrbi. ${ }^{31}$

\subsubsection{Ustupanje predmeta sudu države članice koji je u boljoj poziciji da raspravi i odluči o predmetu}

Sudovi (odnosno tijela prema PBU-u II bis) države članice nadležni s obzirom na predmet spora iznimno mogu zastati s postupkom ili dijelom postupka radi upućivanja predmeta sudu/ tijelu druge države članice ako smatraju da je sud/tijelo te druge države članice s kojim dijete ima osobitu vezu u boljem položaju da odlučuje o tom predmetu te da bi to bilo u interesu djeteta (čl. 15. st. 1. BU-a II bis). Do ustupanja predmeta može doći na zahtjev stranke, po službenoj dužnosti ili na zahtjev suda/tijela druge države članice s kojim dijete ima osobitu vezu (čl. 15. st. 2. BU-a II bis). Ustupanje predmeta po službenoj dužnosti ili na zahtjev suda/ tijela druge države članice, međutim, mora prihvatiti barem jedna od stranaka (čl. 15. st. 2. BU-a II bis). ${ }^{32}$

BU-om II bis određeno je što se smatra "osobitom vezom" djeteta te druge države članice kojoj se predmet ustupa. Smatra se da dijete ima osobitu vezu s drugom državom članicom: (a) ako je u toj državi članici dijete steklo uobičajeno boravište nakon pokretanja postupka pred sudom/tijelom države članice nadležnim za odlučivanje o glavnoj stvari ili

(b) ako je u toj državi članici dijete prije imalo uobičajeno boravište ili

(c) ako je dijete državljanin te države članice ili

(d) ako je u toj državi članici uobičajeno boravište nositelja roditeljske odgovornosti ili

(e) ako se u toj državi članici nalazi imovina djeteta, a predmet se odnosi na mjere zaštite djeteta u odnosu na upravljanje, čuvanje ili raspolaganje njegovom imovinom (čl. 15. st. 3. Uredbe Brisel II bis).

U domaćoj se literaturi mogućnost koju propisuje čl. 15. BU-a II bis označava kao (diskrecijsko) ustupanje nadležnosti ili predmeta, ${ }^{33}$ ili pak prijenos nadležnosti. ${ }^{34}$ Odredba čl. 15. BU-a II bis mogla bi se ocijeniti kao oblik svrsishodne delegacije nadležnosti tijelu druge države članice koje je u boljoj poziciji da riješi konkretni predmet. ${ }^{35} \mathrm{O}$ toj bi delegaciji, međutim, konačno odlučivao sud kojem se nadležnost delegira te ako je ne prihvati, postupak bi trebao nastaviti

31 Za podatke o pojedinim državama članicama v. ibid., str. 33.

32 PBU-om II bis izvršena je renumeracija članaka te je čl. 15. postao čl. 14. Uredbe. Unatoč raspravama o proširenju područja primjene čl. 15. BU-a II bis na sve predmete o roditeljskoj odgovornosti (ne samo na iznimne slučajeve) i u odnosu na treće države koje nisu članice EU-a, u PBU-u II bis nisu prihvaćene izmjene u tom smislu. Vidjeti ibid., str. 126.-127., 175.-178.

33 Medić Musa, I., Komentar Uredbe Bruxelles II bis u području roditeljske skrbi, Pravni fakultet u Osijeku, Osijek, 2012., str. 68.-70. Medić Musa, I., Predmeti o roditeljskoj odgovornosti prema Uredbi Vijeća (EZ) broj 2201/2003 od 27. studenoga 2003. o nadležnosti i priznanju i ovrsi odluka u bračnim predmetima i predmetima roditeljske odgovornosti i o ukidanju Uredbe (EZ) broj 1347/2000, u: Korać Graovac, A., Majstorović, I. (ur.), Europsko obiteljsko pravo, Narodne novine, Zagreb, 2013., str. 244.-245. Župan, M., Međunarodna nadležnost u obiteljskopravnim stvarima - presjek pravne stečevine Europske unije, u: Garašić, J. (ur.), Europsko građansko procesno pravo - izabrane teme, Narodne novine, Zagreb, 2013., str. 161.-162. Bruxelles II.a, op. cit. u bilj. 5, str. 34.-37.

35 Za svrsisihodnu delegaciju u domaćem pravu v. Triva, S., Dika, M., Građansko parnično procesno pravo, VII. izdanje, Narodne novine, Zagreb, 2004., str. 282.-284. 
sud pred kojim je postupak (prvo) pokrenut. Pritom bi se okolnost da je to tijelo u boljoj poziciji da riješi konkretni predmet prosuđivala s obzirom na kriterij "osobite veze" djeteta te druge države članice kako je on postavljen u čl. 15. st. 3. BU-a II bis te najboljeg interesa djeteta. Sud, odnosno tijelo druge države članice kojoj se predmet ustupa, trebao bi dakle u povodu zahtjeva provesti incidentalni postupak kako bi utvrdio postojanje "osobite veze" djeteta te tê države članice, kao i bi li ustupanje predmeta bilo u interesu djeteta.

Ako smatra da su ispunjene pretpostavke za delegaciju nadležnosti, sud (odnosno tijelo prema PBU-u II bis) države članice koje je nadležno s obzirom na predmet spora može zastati s postupkom ili dijelom postupka te pozvati stranke da u roku koji sam odredi podnesu zahtjev za ustupanje cijelog ili dijela predmeta sudu/tijelu druge države članice ili pak zatražiti od suda/tijela te druge države članice da se proglasi nadležnim (čl. 15. st. 1., 4. i 5. BU II bis). Ako u roku koji je odredio sud, odnosno tijelo, stranke ne pokrenu postupak pred sudom/tijelom druge države članice, sud/tijelo pred kojim je pokrenut postupak nastavlja ostvarivati nadležnost u skladu s čl. 8. do čl. 14. BU-a II bis (čl. 15. st. 4. BU-a II bis). Također, ako se sud/tijelo druge države članice kojem je podnesen zahtjev za ustupanje predmeta proglasi nenadležnim ili ne prihvati nadležnost u roku od šest tjedana otkad je pred njim pokrenut postupak, sud/ tijelo pred kojim je (prvo) pokrenut postupak nastavlja ostvarivati nadležnost u skladu s čl. 8 . do čl. 14. BU-a II bis (čl. 15. st. 5. BU-a II bis).

Ako sud/tijelo druge države članice prihvati nadležnost, sud/tijelo pred kojim je (prvo) pokrenut postupak proglasit će se nenadležnim (čl. 15. st. 5. BU II bis). Sud odnosno tijelo države članice kojem je ustupljen predmet ne može više ustupati predmet tijelu druge države članice (t. 13. Preambule BU-a II bis). ${ }^{36}$

Tijekom evaluacije primjene BU-a II bis istaknuto je da se mogućnost ustupanja predmeta koju propisuje čl. 15. Uredbe slabo koristi, odnosno da u pojedinim državama članicama nije zabilježen nijedan takav slučaj. ${ }^{37}$

\subsection{TRENUTAK POKRETANJA POSTUPKA}

BU II bis autonomno određuje trenutak pokretanja postupka pred sudom. Smatra se da je postupak pred sudom pokrenut u trenutku kad je pismeno kojim se pokreće postupak ili drugo odgovarajuće pismeno podneseno sudu pod uvjetom da osoba koja pokreće postupak nije nakon toga propustila poduzeti radnje koje je morala poduzeti u vezi s dostavom pismena protivnoj stranci ili ako pismeno mora biti dostavljeno prije njegova podnošenja sudu, kad ga je primilo tijelo ovlašteno za dostavu pod uvjetom da osoba koja pokreće postupak nije nakon toga propustila poduzeti radnje koje je morala poduzeti kako bi pismeno bilo podneseno sudu (čl. 16. BU-a II bis). ${ }^{38}$

36 Praktični priručnik za primjenu Uredbe Bruxelles II.a, op. cit. u bilj. 5, str. 34.

37 O razlozima (ne)primjene čl. 15. Uredbe v. Analytical Annexes, op. cit. u bilj. 15, str. 34-36.

38 U domaćoj literaturi se uz pojam "pokretanja postupka pred sudom" onako kako ga određuje BU II bis vezuju (materijalnopravni te procesnopravni) učinci litispendencije iako u domaćem procesnom sustavu oni bi nastupali poslije: $u$ trenutku dostave tužbe tuženiku (čl. 194. st. 1. Zakona o parničnom postupku, Službeni list Socijalističke Federativne Republike Jugoslavije, broj 4/1977 - 35/1991; Narodne novine, broj 26/1991, 53/1991, 91/1992, 112/1999, 88/2001 - v. čl. 50. Zakona o arbitraži, 117/2003, 
I PBU II bis zadržao je autonomno određenje trenutka pokretanja postupka pred sudom (pred. čl. 15. PBU-a II bis). ${ }^{39}$ Uzimajući u obzir da je PBU-om II bis slijedeći u tome praksu Suda EU-a proširena definicija tijela koje je nadležno postupati prema BU-u II bis (v. supra ad 2.1.), treba primijetiti da PBU II bis izrijekom ne određuje trenutak pokretanja postupka pred (drugim) tijelom, a što može biti važno u kontekstu primjene odredaba o ispitivanju nadležnosti te postupanju tijela država članica u slučaju paralelnog vođenja postupaka među istim strankama o istom predmetu postupka (čl. 17., čl. 19. PBU-a II bis).

\subsection{ISPITIVANJE NADLEŽNOSTI}

Sud države članice po službenoj dužnosti oglasit će se nenadležnim ako je pokrenut postupak u predmetu za koji taj sud nije nadležan prema odredbama BU-a II bis, a za njega je nadležan sud druge države članice (čl. 17. BU-a II bis). U Uredbi je propisano i postupanje suda u slučaju da su u predmetu o roditeljskoj odgovornosti koji se odnosi na isto dijete, među istim strankama, pokrenuti postupci pred sudovima različitih država članica (čl. 19. BU-a II bis). Pritom su PBU-om II bis citirane odredbe čl. 17. te čl. 19. BU-a II bis proširene na sva "tijela"; dakle sudska i upravna tijela država članica koja su nadležna postupati u okviru materijalnog polja primjene Uredbe (pred. čl. 2. t. 1. PBU-a II bis).

Ako je postupak u predmetu o roditeljskoj odgovornosti o istom zahtjevu i o istom djetetu pokrenut pred sudovima (odnosno tijelima prema PBU-u II bis) različitih država članica, sud/ tijelo pred kojim je postupak pokrenut poslije po službenoj dužnosti zastaje s postupkom dok se ne utvrdi nadležnost suda/tijela pred kojim je postupak prije pokrenut (čl. 19. st. 2. BU-a II bis). Ako se utvrdi nadležnost suda/tijela pred kojim je postupak pokrenut prije, sud/tijelo pred kojim je postupak pokrenut poslije, oglašava se nenadležnim u korist prvog suda/tijela. U tom slučaju stranka koja je pokrenula odgovarajući postupak pred drugim sudom/tijelom može pokrenuti postupak, odnosno podnijeti zahtjev pred sudom/tijelom pred kojim je postupak prvo pokrenut (čl. 19. st. 3. BU-a II bis).

Sud pred kojim je kasnije pokrenut postupak te koji je zastao s postupkom, može nastaviti postupak tek kad se sud pred kojim je pokrenut postupak prije, oglasi nenadležnim (arg. ex čl. 19. st. 3. BU-a II bis) ili kad mu taj sud ustupi predmet zato što smatra da je u boljoj poziciji da u njemu postupa (arg. ex čl. 15. BU-a II bis; v. supra ad 2.2.2.2.). ${ }^{40}$ Tomu bi, čini se, trebalo pridodati i mogućnost da stranke nakon što je pokrenut postupak u predmetu o roditeljskoj odgovornosti, naknadno pokrenu postupak u bračnom sporu te prorogiraju nadležnost tog suda (pred kojim je pokrenut postupak u bračnom sporu) za odlučivanje i o predmetu o roditeljskoj odgovornosti u odnosu na isti zahtjev i o istom djetetu (arg. ex čl. 12. st. 1. BU-a II bis). U tom slučaju, treba uzeti, da bi se sud pred kojim je prije pokrenut postupak u predmetu u

88/2005 - v. čl. 129. Zakona o izmjenama i dopunama Ovršnog zakona, 2/2007 - v. Odluku Ustavnog suda Republike Hrvatske od 20. prosinca 2006., 84/2008, 96/2008 - v. Odluku Ustavnog suda Republike Hrvatske od 9. srpnja 2008., $123 / 2008$ ispravak, 57/2011, 148/2011 - pročišćeni tekst, 25/2013, 89/2014 - v. Odluku Ustavnog suda Republike Hrvatske od 11. srpnja 2014.; u daljnjem tekstu: ZPP). Vidjeti Medić Musa, Komentar..., op. cit. u bilj. 33, str. 77. Medić Musa, Predmeti..., op. cit. u bilj. 33, str. 246.-247., s bibliografskim uputama. 
roditeljskoj odgovornosti treba oglasiti nenadležnim u korist suda kojem su stranke prorogirale nadležnost da o tome odlučuje uz bračni spor, naravno, ako smatra da bi to bilo u interesu djeteta (arg. ex čl. 12. st. 1. BU-a II bis; v. supra ad 2.2.2.1.).

Sa stajališta učinkovitosti postupka, posebice uzimajući u obzir da se odlučuje o predmetima o roditeljskoj odgovornosti, zanimljivo je pitanje koliko bi dugo trebao čekati sud/tijelo države članice pred kojim je kasnije pokrenut postupak da se sud/tijelo pred kojim je prije pokrenut postupak izjasni o svojoj nadležnosti. Sud EU-a istaknuo je da treba uzeti u obzir "razuman rok", dok pri utvrđivanju tog roka treba uzeti u obzir "interes djeteta u posebnim okolnostima predmetnog postupka" ${ }^{41}$

\section{NADLEŽNOST U (ADHEZIJSKIM) SPOROVIMA O RODITELJSKOJ SKRBI U DOMAĆEM PRAVU}

\subsection{OPĆENITO}

Prema ObZ-u 15, spor o roditeljskoj skrbi može se voditi samostalno (čl. 368. t. 3., čl. 408. st. 1., čl. 409. st. 1. ObZ-a 15) ili adhezijski, pridruženo uz brakorazvodni postupak (čl. 412., čl. 413. st. 1. t. 1. ObZ-a 15) te uz određene druge obiteljske sporove (čl. 412., čl. 413. st. 1. t. 2. ObZ-a 15). Ako bračni drugovi imaju zajedničko maloljetno dijete, dužni su prije pokretanja sudskog postupka radi razvoda braka sudjelovati u obveznom savjetovanju (čl. 54. st. 1. ObZ-a 15), a ako ne sastave plan o zajedničkoj roditeljskoj skrbi do okončanja obveznog savjetovanja, bračni drugovi dužni su u načelu ${ }^{42}$ pristupiti prvom sastanku obiteljske medijacije (čl. 54. st. 3. ObZ-a 15).

U nastavku rada analizirat će se i raspraviti odredbe ObZ-a 15 o (atrakcijskoj) nadležnosti, kao i odredbe ZRSZ-a o međunarodnoj nadležnosti, za sporove o roditeljskoj skrbi.

\subsection{POSEBNO O NADLEŽNOSTI U (ADHEZIJSKIM) SPOROVIMA O RODITELJSKOJ SKRBI}

Prema ObZ-u 15, za suđenje u sporovima o roditeljskoj skrbi nadležan je sud koji je opće mjesno nadležan za dijete (čl. 409. st. 4. ObZ-a 15). Opće mjesno nadležan sud određen je ZPP-om (čl. 46. st. 1. ZPP-a). To bi bio sud prebivališta djeteta (neovisno o tome u kojoj se stranačkoj ulozi nalazi dijete) (arg. ex: čl. 47. st. 1. ZPP-a u vezi s čl. 346. ObZ-a 15). Tako odre-

41 Predmet C-296/10, Bianca Purrucker v. Guillermo Valles Perez [2010], ECR I-11163 od 9. studenog 2010., Praktični priručnik za primjenu Uredbe Bruxelles II.a, op. cit. u bilj. 5, str. 39. Odluka dostupna na: URL=http://curia.europa.eu/juris/document/ document.jsf;jsessionid=9ea7d0f130d6b5aec1cad58747b095d18a473eedbae9.e34KaxiLc3eQc40LaxqMbN4 PahmRe0 text=\&docid=79166\&pageIndex=0\&doclang=EN\&mode=lst\&dir=\&occ=first\&part=1\&cid=814531. Pristupljeno 3. ožujka 2017.

42 Dužnost pristupanja prvom sastanku obiteljske medijacije ne odnosi se na slučajeve kad se prema ObZ-u 15 ne provodi obiteljska medijacija (čl. 332., čl. 54. st. 3. ObZ-a 15). 
đena općemjesna nadležnost bila bi parcijalna, ograničena te specifična. Parcijalna, stoga što bi se primjenjivala samo za zasnivanje nadležnosti među određenim strankama te u odnosu na određeni predmet spora. Specifična, stoga što bi se njome (djelomično) odstupilo od načela actor sequitur forum rei. ${ }^{43}$ Među ostalim, odredba čl. 409. st. 4 . ObZ-a 15 imala bi i značenje odredbe o isključivoj mjesnoj nadležnosti u smislu da bi se njome isključivala nadležnost suda koji bi inače prema ZPP-u bio opće mjesno nadležan, ali treba uzeti i drugo (potencijalno) posebno mjesno nadležnog suda (arg. ex čl. 409. st. 4. ObZ-a 15).

Ako je nakon pokretanja postupka u sporu o roditeljskoj skrbi došlo do pokretanja brakorazvodnog postupka, ObZ 15 propisuje dužnost suda da spoji taj postupak s postupkom u bračnom sporu (čl. 412. ObZ-a 15). Citirana odredba čl. 412. ObZ-a 15 zapravo omogućava atrakciju nadležnosti za spor o roditeljskoj skrbi, i to suda pred kojim je pokrenut brakorazvodni postupak. ${ }^{44} \mathrm{~S}$ obzirom na to da bi ta (naknadna) atrakcija nadležnosti bila isključiva, u sporovima o roditeljskoj skrbi ne bi vrijedilo načelo ustaljivanja nadležnosti kako je ono postavljeno ZPP-om. ${ }^{45}$

Ako nije pokrenut spor o roditeljskoj skrbi a jedan od bračnih drugova pokrene spor radi razvoda braka, u okviru pokrenutog brakorazvodnog postupka sud je dužan po službenoj dužnosti odlučiti s kojim će roditeljem dijete stanovati, o ostvarivanju roditeljske skrbi i osobnih odnosa s djetetom (te uzdržavanju djeteta) (čl. 413. st. 1. t. 1. ObZ-a 15). I u ovom slučaju ObZ 15 omogućava atrakciju nadležnosti za spor o roditeljskoj skrbi, i to suda koji odlučuje u brakorazvodnom postupku.

ZRSZ - koji je do 1. srpnja 2013. vrijedio u Hrvatskoj prema državama članicama EU-a - za sporove o roditeljskoj skrbi, osim općeg pravila o međunarodnoj nadležnosti (čl. 46. st. 1. ZRSZ-a), ${ }^{46}$ sadrži posebnu odredbu o toj nadležnosti (čl. 66. ZRSZ-a). Nadležnost suda Republike Hrvatske postoji u "sporovima o čuvanju, podizanju i odgoju djece koja su pod roditeljskim staranjem” i kad tuženik nema prebivalište u Republici Hrvatskoj ako su oba roditelja hrvatski državljani (čl. 66. st. 1. ZRSZ-a). Ako su tuženik i dijete hrvatski državljani i ako oboje imaju prebivalište u Republici Hrvatskoj, nadležnost suda Republike Hrvatske je isključiva (čl. 66. st. 2. ZRSZ-a).

Treba primijetiti da ZRSZ ne sadrži pravilo o međunarodnoj nadležnosti za sporove o ostvarivanju osobnih odnosa djeteta s roditeljem s kojim ne stanuje, nego samo za "čuvanje, podizanje i odgoj djece". ${ }^{47}$ Naravno, djelomice je to posljedica okolnosti što je riječ o bivšem saveznom propisu koji je bio preuzet u hrvatsko zakonodavstvo te u kojemu se i dalje koristi zastarjela terminologija. Drugo, odredbe o međunarodnoj nadležnosti u sporovima o "čuva-

43 To bi vrijedilo u svim onim slučajevima kada bi u procesnoj ulozi tužitelja bilo dijete.

44 O pojmu atrakcije nadležnosti v. Triva, Dika, op. cit. u bilj. 35, str. 279.

45 Prema čl. 15. ZPP-a, sud ocjenjuje po službenoj dužnosti, odmah nakon primitka tužbe, je li nadležan i u kojem je sastavu nadležan. To ocjenjivanje nadležnosti obavlja se na temelju navoda u tužbi i na temelju činjenica koje su sudu poznate. Ako se tijekom postupka promijene okolnosti na kojima je utemeljena nadležnost suda, sud koji je bio nadležan u vrijeme podnošenja tužbe ostaje i dalje nadležan i ako bi zbog tih promjena bio nadležan drugi sud iste vrste ili sud druge vrste, ako zakonom nije izrijekom drukčije određeno.

46 Nadležnost suda Republike Hrvatske postoji ako tuženik ima prebivalište (odnosno sjedište) u Republici Hrvatskoj (čl. 46. st. 1. ZRSZ-a).

47 Usp. Dika, M.; Knežević, G.; Stojanović, S., Komentar Zakona o međunarodnom privatnom i procesnom pravu; Zakon o rješavanju sukoba zakona sa propisima drugih zemalja u određenim odnosima, PiP “NOMOS”, Beograd, 1991., str. 222. 
nju, podizanju i odgoju djece" nisu u skladu s (odredbama prava EU-a te) odredbama ObZ-a 15 o mjesnoj nadležnosti za te sporove. Dok ZRSZ koristi kriterij prebivališta tuženika, ObZ 15 je prihvatio kriterij prebivališta djeteta. ${ }^{48}$ Osim toga, ZRSZ ne sadrži odredbe o atrakciji međunarodne nadležnosti za sporove o roditeljskoj skrbi koji se vode uz brakorazvodne i druge obiteljske sporove. ${ }^{49}$

U sporovima o roditeljskoj skrbi prorogacija međunarodne nadležnosti stranog suda, kao i domaćeg suda nije dopuštena (čl. 49. ZRSZ-a). ${ }^{50} \mathrm{ObZ} 15$ izrijekom ne isključuje mogućnost sklapanja sporazuma o nadležnosti a time i prorogacije mjesne nadležnosti u sporovima o roditeljskoj skrbi. ${ }^{51}$ Čini se, međutim, da bi sporazum o (mjesnoj) nadležnosti u sporovima o roditeljskoj skrbi bio isključen ako bi se prihvatilo shvaćanje da odredba čl. 409. st. 4. ObZ-a 15 ima značenje odredbe o isključivoj mjesnoj nadležnosti (arg. ex čl. 70. st. 1. ZPP-a), odnosno da bi atrakcija nadležnosti uz brakorazvodni postupak bila isključiva (arg. ex: čl. 412., čl. 413. st. 1. t. 1. ObZ-a 15).

Različito od prava EU-a, ${ }^{52}$ niti ZRSZ niti ObZ 15 ne propisuju mogućnost ustupanja predmeta o roditeljskoj skrbi sudu koji bi bio u boljoj poziciji da provede postupak. ${ }^{53}$

\section{PRIMJENA BRISELSKE UREDBE II BIS U HRVATSKOJ: OTVORENA IMPLEMENTACIJSKO-PRAKTIČNA PITANJA}

Primjena odredaba o nadležnosti BU-a II bis otvara određena implementacijsko-praktična pitanja:

(1) U kontekstu ispitivanja nadležnosti u predmetima o roditeljskoj skrbi, bi li se trenutak "pokretanja postupka pred sudom" prema BU-u II bis trebao smatrati trenutak pokretanja postupka obveznog savjetovanja prema ObZ-u 15 ili tek trenutak podnošenja tužbe hrvatskom sudu? Naznačeno je pitanje posebice važno uzme li se u obzir teza da dok traje postupak obveznog savjetovanja pred hrvatskim centrom za socijalnu skrb, jedan od bračnih drugova/roditelja mogao bi pokrenuti sudski postupak u drugoj državi članici EU-a, i to kako brakorazvodni postupak tako i samostalni postupak o roditeljskoj skrbi.

48 U pravu EU-a odlučujući kriterij uobičajeno je boravište djeteta (v. supra ad 2.2.1.).

49 U domaćoj (i bivšoj jugoslavenskoj) doktrini javila su se različita shvaćanja o tome mogu li se iz odredaba o mjesnoj (te atrakcijskoj) nadležnosti izvoditi pravila o međunarodnoj (atrakcijskoj) nadležnosti za sve one situacije koje nisu izrijekom propisane ZRSZom. Vidjeti Dika; Knežević; Stojanović, op. cit. u bilj. 47, str. 224. Triva, Dika, op. cit. u bilj. 35, str. 259.-260. Župan, op. cit. u bilj. 33, str. 166.

51 S druge strane, općim odredbama ObZ-a 15 koje se primjenjuju u obiteljskim izvanparničnim postupcima izrijekom je isključena mogućnost prorogacije nadležnosti (čl. 435. st. 2. ObZ-a 15).

52 Vidjeti supra ad 2.2.2.2.

53 U općim odredbama ObZ-a 15 koje se međutim primjenjuju u obiteljskim izvanparničnim postupcima propisana je mogućnost ustupanja predmeta sudu, ali pod drukčijim pretpostavkama od onih propisanim BU-om II bis. ObZ 15 mogućnost ustupanja predmeta vezuje uz promjenu okolnosti na kojima se temelji mjesna nadležnost te (odstupajući od pravila perpetuatio fori) omogućava ustupanje predmeta sudu koji je postao mjesno nadležan ako je očito da će se tako lakše provesti postupak ili ako je to potrebno radi zaštite osoba o kojima sud vodi osobitu brigu (čl. 435. st. 1. ObZ-a 15). 
U domaćem pravu (parnični) postupak pred sudom pokreće se tužbom (čl. 185. ZPP-a). Specifičnost je, međutim, postupaka u sporovima radi razvoda braka, kao što je već istaknuto, da pokretanju postupka pred sudom prethodi pokretanje postupka obveznog savjetovanja pred centrom za socijalnu skrb te (eventualno) obiteljske medijacije pred obiteljskim medijatorom (čl. 54. st. 1., 3. i 4. ObZ-a 15). Navedeni izvansudski postupci mirnog rješavanja obiteljskopravnih sporova imaju značenje posebnih procesnih pretpostavaka bez kojih nije dopušteno pokretanje sudskog postupka radi razvoda braka te o roditeljskoj skrbi (arg. ex: čl. 379., čl. 410. ObZ-a 15). Stoga moglo bi se tvrditi da se procesnopravni učinci pokretanja brakorazvodnog postupka (odnosno samostalnog postupka u sporu o roditeljskoj skrbi) trebaju vezivati uz trenutak pokretanja postupka obveznog savjetovanja pred centrom za socijalnu skrb, a ne tek u trenutku podnošenja tužbe sudu.

Odgovor na supra ad (1) navedeno pitanje zahtijeva odgovor na prethodna dva pitanja: ima li se centar za socijalnu skrb koji provodi postupak obveznog savjetovanja smatrati "sudom", posebice u smislu dužnosti "suda" da ispita svoju nadležnost sukladno BU-u II bis te bi li se postupak obveznog savjetovanja mogao smatrati postupkom uz koji bi se vezivala postupovna jamstva koja se inače vezuju uz sudski postupka u kojem se rješava o pitanjima roditeljske skrbi?

BU II bis definira pojam "sudac" kao suca ili drugog službenika s ovlastima koje odgovaraju onima koje ima sudac u predmetima koji potpadaju pod polje primjene BU-a II bis (čl. 2. t. 2. BU II bis). Teško da bi se članovi tima centra za socijalnu skrb ${ }^{54}$ koji provode postupak obveznog savjetovanja te opis njihovih ovlasti i zadaća u tom postupku ${ }^{55}$ mogli podvesti pod pojam "sudac" onako kako ga definira BU II bis. Uz to, postupak obveznog savjetovanja kao metoda stručne "pomoći” članovima obitelji (čl. 321. st. 1. ObZ-a 15) nema obilježja (sudskog) postupka u kojem se "odlučuje" o predmetima iz materijalnog polja primjene BU-a II bis, a niti postupovna jamstva sudskog postupka u kojem bi se na samom početku postupka ispitivala nadležnost po službenoj dužnosti sukladno BU-u II bis. ${ }^{56}$

Trebalo bi zauzeti stav da se postupak radi razvoda braka (te samostalan postupak o roditeljskoj skrbi) pokreće podnošenjem tužbe sudu te da se uz taj trenutak vezuju procesnopravni učinci "pokretanja postupka" sukladno BU-u II bis. ${ }^{57}$ Stoga bi jedna od stranaka mogla u drugoj državi članici EU-a pokrenuti brakorazvodni postupak ili (samostalan) postupak o roditelj-

54 Vidjeti čl. 321. st. 2. ObZ-a 15; čl. 4. Pravilnika o obveznom savjetovanju iz 2015., Narodne novine, broj 123/2015 (u daljnjem tekstu: POS).

55 Vidjeti čl. od 321. do 330. ObZ-a 15 te POS.

56 O tumačenju pojma "sud" odnosno "tijelo" u praksi Suda EU-a v. supra ad 2.1. te bilj. 11.

57 Slično pitanje javilo se u Francuskoj u kojoj se brakorazvodni postupak sastoji od dva dijela: najprije se podnosi inicijalni zahtjev te sudac provodi pokušaj mirenja bračnih drugova; ako sudac utvrdi da mirenje nije uspjelo, jedan ili oba bračna druga mogu podnijeti zahtjev za razvod braka (čl. 252. - čl. 252-3. Građanskog zakonika). U kontekstu određivanja trenutka pokretanja postupka sukladno BU-u II bis, francuski Cour de cassation zauzeo je stav da se brakorazvodni postupak pokreće podnošenjem inicijalnog zahtjeva pod uvjetom da se poslije podnese tužba za razvod braka (Chambre civile 1, 11. srpnja 2006., broj 0420.405 i broj 05-19.231, Bulletin 2006 I No 374, str. 320, URL=https://www.legifrance.gouv.fr/affichJuriJudi.do?idTexte= JURITEXT000007055728. Pristupljeno 3. siječnja 2017. No 375, str. 322, URL=https://www.legifrance.gouv.fr /affichJuriJudi. do?oldAction=rechJuriJudi\&idTexte=JURITEXT000007053888\&fastReqId=1825586529\&fastPos=1. Pristupljeno 3. siječnja 2017.). Analytical Annexes, op. cit. u bilj. 15, str. 43. Razlika u odnosu na hrvatsko pravo jest u tome što se i prvi dio postupka provodi pred sudom; dakle mirenje bračnih drugova provodi sudac. Osim toga, (primarni) cilj prvog dijela postupka izmirenje je bračnih drugova (te određivanje privremenih mjera), dok je u hrvatskom pravu (primarni) cilj obveznog savjetovanja postizanje plana o zajedničkoj roditeljskoj skrbi; dakle postizanje sporazuma o pitanjima za koja postoji nadležnost hrvatskog suda prema BU-u II bis u načelu samo ako roditelji pristanu na prorogaciju nadležnosti sudu koji odlučuje u brakorazvodnom postupku. 
skoj skrbi iako je u Hrvatskoj u tijeku postupak obveznog savjetovanja. Pritom bi hrvatski sud bio dužan - ako dođe do pokretanja sudskog postupka u Hrvatskoj - zastati sa sudskim postupkom dok sud druge države članice pred kojim je prvo pokrenut postupak ne odluči o svojoj nadležnosti prema BU-u II bis. Takve situacije, naravno, djeluju ograničavajuće na bilo koju inicijativu te poticanje stranka na korištenje obiteljske medijacije kao prikladnog načina rješavanja sporova o roditeljskoj skrbi. ${ }^{58}$

(2) Uzimajući u obzir direktnu primjenu BU-a II bis, bi li stranka mogla prvo pokretati postupak radi razvoda braka pred sudom, a potom bi ju sud upućivao na obvezno savjetovanje o kojem rezultatu bi ovisio nastavak postupka - parničnog, ako nije postignut plan o zajedničkoj roditeljskoj skrbi (čl. 409. ObZ-a 15), ili izvanparničnog radi odobravanja plana o zajedničkoj roditeljskoj skrbi (čl. 461. ObZ-a 15)? To pod pretpostavkom da su nositelji roditeljske odgovornosti suglasni s prorogacijom nadležnosti hrvatskom sudu pred kojim je u tijeku brakorazvodni postupak ili da su inače ispunjeni kriteriji da postupak vodi hrvatski sud u predmetima o roditeljskoj skrbi.

Prilikom razmatranja navedenog pitanja trebalo bi u prvom redu uzeti u obzir načelo direktne primjene europskog prava ako je domaće pravo u suprotnosti s europskim, odnosno načelo usklađenog tumačenja nacionalnog prava s europskim. ${ }^{59}$ Iako domaće pravo propisuje specifičnu koncentraciju postupaka te oficijelne dužnosti suda da uz brakorazvodni postupak odluči i o pitanjima roditeljske skrbi zajedničkog maloljetnog djeteta, pravo EU-a zauzelo je suprotan princip: načelo stranačke autonomije. Od dispozicije stranaka zavisi ne samo pokretanje postupka u predmetima o roditeljskoj skrbi već i pitanje nadležnosti suda u tim predmetima (v. supra ad 2.2.2.1.).

Ako bračni drugovi ne bi pristali na prorogaciju nadležnosti sukladno BU-u II bis u predmetima o roditeljskoj skrbi (ili inače ne bi bili ispunjeni kriteriji za zasnivanje nadležnosti hrvatskog suda u predmetima o roditeljskoj skrbi), brakorazvodni postupak bi se mogao nastaviti samo kao spor o razvodu braka. U tom slučaju uopće ne bi postojala potreba za provođenjem postupka obveznog savjetovanja (budući da hrvatski sud uopće ne bi bio nadležan odlučivati o pitanjima koja se odnose na djecu). Trebalo bi pritom zauzeti negativan stav prema mogućnosti da sud po službenoj dužnosti odluči o pitanjima koja se odnose na zajedničku maloljetnu djecu pozivom na lex fori ako ne bi bile ispunjene pretpostavke prorogacije nadležnosti hrvatskom sudu prema BU-u II bis.

Uzimajući u obzir izneseno, izravna primjena BU-a II bis u sporu o roditeljskoj skrbi zahtijevala bi da stranka najprije pokrene postupak radi razvoda braka pred sudom, a potom da sud stranke - ako utvrdi da su ispunjene pretpostavke nadležnosti hrvatskog suda u predmetima o roditeljskoj skrbi prema BU-u II bis - uputi na obvezno savjetovanje o rezultatu kojeg bi ovi-

58 Okolnost da BU II bis sadrži alternativne poveznice za zasnivanje nadležnosti u bračnim predmetima, uzimajući u obzir i pravilo o pokretanju postupka pred sudom (čl. 19. BU-a II bis), kao i razlike između nacionalnih pravila država članica, može poticati forum shopping. V. Sud EU-a: C-168/08, Laszlo Hadadi (Hadady) v. Csille Marte Mesko, udane Hadadi (Hadady) [2009], ECR I-6871 od 16. srpnja 2009. Dostupna na: URL=http://curia.europa.eu/juris/document/document. jsf?text=\&docid=72471\&pageIndex=0\&doclang $=E N \& m o d e=l s t \&$ dir $=\& o c c=$ first\&part=1\&cid=815385. Pristupljeno 3. ožujka 2017. Među praktičarima država članica EU-a upravo je forum shopping problem, odnosno rush to court problem istaknut kao ograničavajuća okolnost u razvoju mirnih načina rješavanja obiteljskopravnih sporova, posebice medijacije. Strankama se savjetuje da (što prije) pokreću sudske postupke kako bi se "osigurale" od okolnosti da drugi bračni drug pokrene postupak u drugoj državi članici u kojoj bi vođenje postupka bilo za njega nepovoljno. Analytical Annexes, op. cit. u bilj. 15, str. 17-20. 
sio nastavak sudskog postupka - parničnog, ako nije postignut plan o zajedničkoj roditeljskoj skrbi ili izvanparničnog radi odobravanja plana o zajedničkoj roditeljskoj skrbi.

(3) Bi li odredba ObZ-a 15 - prema kojoj sud ex offo odlučuje o pitanjima koja se odnose na djecu - ujedno imala značenje odredbe o atrakciji međunarodne nadležnosti hrvatskog suda?

BU II bis (kao ni ZRSZ) ne propisuju atrakciju nadležnosti u predmetima o roditeljskoj skrbi onako kako je ona postavljena domaćim ObZ-om 15. Prema BU-u II bis mogućnost da sud koji odlučuje o razvodu braka raspravlja i u predmetu o roditeljskoj skrbi ovisi o suglasnosti stranaka i nositelja roditeljske odgovornosti. Uz to, pravilo prema kojemu se BU II bis primjenjuje uvijek kada o predmetu koji ulazi u materijalno polje njezine primjene treba odlučiti sud države članice, osim suda Danske, određivalo bi teritorijalno polje njezine primjene, a ujedno i pravilo da bi hrvatski sud uvijek u predmetima o roditeljskoj skrbi (s međunarodnim elementom) izravno i neposredno primjenjivao odredbe BU-a II bis. ${ }^{60}$

Ako dijete ne bi imalo uobičajeno boravište u jednoj od država članica EU-a, niti bi se ono nalazilo na teritoriju jedne od država članica, a ne bi bile ni ispunjene pretpostavke za prorogaciju nadležnosti suda (koji inače postupa u bračnom sporu), nadležnost bi se utvrđivala prema nacionalnom pravu (čl. 14. BU-a II bis). U tim okolnostima - primjene lex fori - treba uzeti da bi bilo moguće zasnovati nadležnost hrvatskog suda u predmetima o roditeljskoj skrbi na temelju atrakcijskog kriterija sadržanog u ObZ-u 15 (arg. ex čl. 27. ZPP-a). ${ }^{61}$

(4) Bi li postojao identitet spora ako je u Hrvatskoj u tijeku brakorazvodni postupak, a pred sudom druge države članice EU-a pokrene se (samostalan) postupak o roditeljskoj skrbi, posebice s obzirom na oficijelne dužnosti suda prema domaćem izvoru (ObZ-u 15) da odluči o pitanjima roditeljske skrbi zajedničkog maloljetnog djeteta?

Dok je prema domaćem pravu dovoljno za zasnivanje nadležnosti u (adhezijskim) predmetima o roditeljskoj skrbi da su bračni drugovi pokrenuli brakorazvodni postupak, prema BU-u II bis tom se pitanju pristupa u kontekstu prorogacije nadležnosti te se za zasnivanje nadležnosti u tim predmetima traži suglasnost stranaka i nositelja roditeljske skrbi. Stoga, u odnosu na naznačeno pitanje supra ad (4), treba uzeti da ne bi postojao identitet spora ako bračni drugovi i nositelji roditeljske skrbi nisu pristali na prorogaciju nadležnosti hrvatskog suda i za (adhezijske) predmete o roditeljskoj skrbi. Budući da BU II bis traži suglasnost za zasnivanje (prorogacije) nadležnosti u predmetima o roditeljskoj skrbi, to bi ujedno značilo i da bračni drugovi moraju staviti zahtjev da sud odluči o tim pitanjima; dakle sud ne bi mogao po službenoj dužnosti odlučiti o pitanjima koja se odnose na roditeljsku skrb sukladno BU-u II bis.

Okolnosti da je u tijeku (samostalni) postupak o roditeljskoj skrbi u drugoj državi članici EU-a, ne sprječava hrvatski sud koji odlučuje u brakorazvodnom postupku da odredi, prema lex fori, privremenu mjeru s kojim će roditeljem dijete stanovati i o ostvarivanju osobnih odnosa s djetetom (čl. 20. BU-a II bis/čl. 12. PBU-a II bis; čl. 536. ObZ-a 15).

$60 \quad$ Usp. Medić Musa, Predmeti..., op. cit. u bilj. 33, str. 235.

61 Za različita shvaćanja u literaturi v. supra ad bilj. 49. 


\section{ZAKLJUČNE NAPOMENE}

Iako su PBU-om II bis učinjeni znatni pomaci u pojedinim područjima njezina polja primjene ${ }^{62}$ nažalost, nije se iskoristila mogućnost prepoznavanja i poticanja mirnog rješavanja sporova do kojih dolazi zbog razvoda braka, posebice sporova o roditeljskoj skrbi. Time se i dalje pogoduje problemu rush to court.

Polazeći od načela autonomnog tumačenja pojma "pokretanje postupka pred sudom", u međuvremenu, trebalo bi zauzeti stav da bi izravna primjena BU-a II bis u sporu o roditeljskoj skrbi zahtijevala da stranke najprije pokrenu postupak radi razvoda braka pred sudom, a potom da ih sud - nakon što utvrdi da su ispunjene pretpostavke nadležnosti hrvatskog suda u predmetima o roditeljskoj skrbi prema Uredbi - uputi na obvezno savjetovanje o rezultatu kojeg bi ovisio nastavak sudskog postupka - parničnog, ako nije postignut plan o zajedničkoj roditeljskoj skrbi ili izvanparničnog radi odobravanja plana o zajedničkoj roditeljskoj skrbi.

Unatoč uspostavljenim načelima tumačenja prava EU-a, trebalo bi, de lege ferenda, razmisliti da se u NP ZMPP-u izrijekom propiše da se u sporovima o roditeljskoj skrbi iz materijalnog polja primjene BU-a II bis postupak najprije pokreće pred sudom pa da sud onda - nakon ispitivanja nadležnosti prema Uredbi - upućuje stranke na postupak obveznog savjetovanja.

BU II bis sadrži pojedine kriterije za zasnivanje nadležnosti u predmetima o roditeljskoj skrbi koje ne nalazimo u domaćem pravu (iako mu ti kriteriji nisu strani). To se ponajprije odnosi na ustupanje predmeta sudu države članice koji je u boljoj poziciji da raspravi predmet o roditeljskoj skrbi te prorogaciju nadležnosti sudu države članice koji raspravlja o bračnom sporu. Trebalo bi, de lege ferenda, razmisliti o uvođenju tih kriterija kako u domaći izvor međunarodnog privatnog prava i postupka, ${ }^{63}$ ali - u odnosu na domaće situacije - i u pravila o mjesnoj nadležnosti ObZ-a 15. To bi zahtijevalo i da se preispitaju odredbe ObZ-a 15 o oficijelnim ovlastima suda da odlučuje o pitanjima roditeljske skrbi uz bračni spor.

\section{LITERATURA}

1. Craig, P., de Búrca, G., EU Law, Text, Cases, and Materials, 6th ed., Oxford University Press, Oxford, 2015.

2. Ćapeta, T., Sudovi Europske unije: Nacionalni sudovi kao europski sudovi, Institut za međunarodne odnose, Zagreb, 2002.

3. Ćapeta, T., Sudski sustav Europske unije i njegov utjecaj na procesna prava država članica, u: Garašić, J. (ur.), Europsko građansko procesno pravo - izabrane teme, Narodne novine, Zagreb, 2013., str. 33. -55.

4. De Boer, Th. M., What we should not expect from a recast of the Brussels IIbis Regulation, str. 10.-19. URL=http://www.nipr-online.eu/upload/documents/2015033 1T124932-NIPR\%202015-1-De\% 20Boer-sample\%20copy.pdf. Pristupljeno 20. prosinca 2016.

62 Vidjeti Explanatory memorandum, op. cit. u bilj. 9, str. 12.-17.

63 U NP ZMPP-u nadležnost u predmetima o roditeljskoj skrbi određuje se, među ostalim, upućivanjem na BU II bis (pred. čl. 51 . NP ZMPP-a). 
5. Dika, M.; Knežević, G.; Stojanović, S., Komentar Zakona o međunarodnom privatnom i procesnom pravu; Zakon o rješavanju sukoba zakona sa propisima drugih zemalja u određenim odnosima, PiP "NOMOS”, Beograd, 1991.

6. Medić Musa, I., Komentar Uredbe Bruxelles II bis u području roditeljske skrbi, Pravni fakultet u Osijeku, Osijek, 2012.

7. Medić Musa, I., Predmeti o roditeljskoj odgovornosti prema Uredbi Vijeća (EZ) broj 2201/2003 od 27. studenoga 2003. o nadležnosti i priznanju i ovrsi odluka u bračnim predmetima i predmetima roditeljske odgovornosti i o ukidanju Uredbe (EZ) broj 1347/2000, u: Korać Graovac, A., Majstorović, I. (ur.), Europsko obiteljsko pravo, Narodne novine, Zagreb, 2013., str. 231.-265.

8. Nademleinsky, M., Neumayr, M., Internationales Familienrecht, Facultas Verlags- und Buchhandels, Wien, 2007.

9. Triva, S., Dika, M., Građansko parnično procesno pravo, VII. izdanje, Narodne novine, Zagreb, 2004.

10. Župan, M., Međunarodna nadležnost u obiteljskopravnim stvarima - presjek pravne stečevine Europske unije, u: Garašić, J. (ur.), Europsko građansko procesno pravo - izabrane teme, Narodne novine, Zagreb, 2013., str. 147.-170.

\section{POPIS PROPISA}

1. Haška konvencija o nadležnosti, mjerodavnom pravu, priznanju, ovrsi i suradnji u odnosu na roditeljsku skrb i mjere za zaštitu djece iz 1996., Narodne novine, Međunarodni ugovori, broj 5/2009.

2. Obiteljski zakon iz 2015., Narodne novine, broj 103/2015.

3. Pravilnik o obveznom savjetovanju iz 2015., Narodne novine, broj 123/2015.

4. Uredba Vijeća (EZ) broj 2201/2003 o nadležnosti i priznanju i ovrsi odluka u bračnim predmetima i predmetima roditeljske odgovornosti, kojom se ukida Uredba (EZ) broj 1347/2000, Official Journal of the European Union, broj L 338, str. 1.-29.

5. Uredba Vijeća (EZ) broj 4/2009 o nadležnosti, mjerodavnom pravu, priznanju i ovrsi odluka te suradnji u stvarima uzdržavanja, Official Journal of the European Union, broj L 7, str. 1.-79.

6. Zakon o parničnom postupku, Službeni list Socijalističke Federativne Republike Jugoslavije, broj 4/1977 - 35/1991; Narodne novine, broj 26/1991, 53/1991, 91/1992, 112/1999, 88/2001 - v. čl. 50. Zakona o arbitraži, 117/2003, 88/2005 - v. čl. 129. Zakona o izmjenama i dopunama Ovršnog zakona, 2/2007 - v. Odluku Ustavnog suda Republike Hrvatske od 20. prosinca 2006., 84/2008, 96/2008 - v. Odluku Ustavnog suda Republike Hrvatske od 9. srpnja 2008., 123/2008 - ispravak, 57/2011, 148/2011 - pročišćeni tekst, 25/2013, 89/2014 - v. Odluku Ustavnog suda Republike Hrvatske od 11. srpnja 2014.

7. Zakon o rješavanju sukoba zakona s propisima drugih zemalja u određenim odnosima, Narodne novine, broj 53/1991, 88/2001.

\section{POPIS SUDSKIH ODLUKA}

1. Cour de cassation: Chambre civile 1, broj 04-20.405, Bulletin 2006 I No 374, str. 320., od 11. srpnja 2006. URL=https://www.legifrance.gouv.fr/affichJuriJudi.do?id Texte =JURITEXT000007055728. Pristupljeno 3. siječnja 2017. 
2. Cour de cassation: Chambre civile 1, broj 05-19.231 No 375, str. 322., od 11. srpnja 2006. URL https://www.legifrance.gouv.fr/affichJuriJudi.do?oldAction=rechJuriJudi \&idTexte=JURITEXT00 0007053888\&fastReqId=1825586529\&fastPos=1. Pristupljeno 3. siječnja 2017.

3. Sud EU-a: C-168/08, Laszlo Hadadi (Hadady) v. Csille Marte Mesko, udane Hadadi (Hadady) [2009], ECR I-6871 od 16. srpnja 2009. Dostupna na: URL=http://curia.europa.eu/juris/document/document.jsf?text=\&docid=72471\&pageIndex=0\&doclang=EN\&mode=lst\&dir=\&occ=first \&part $=1 \&$ cid=815385. Pristupljeno 3. ožujka 2017.

4. Sud EU-a: C-296/10, Bianca Purrucker v. Guillermo Valles Perez [2010], ECR I-11163 od 9. studenog 2010. Dostupna na: URL=http://curia.europa.eu/juris/document/ document.jsf;jsessionid=9ea7d0f130d6b5aec1cad58747b095d18a473eedbae9.e34KaxiLc3eQc40LaxqMbN4PahmRe0?text=\&docid=79166\&pageIndex=0\&doclang=EN\&mode=lst\&dir $=\& o c c=$ first $\&$ par $\mathrm{t}=1 \& \mathrm{cid}=814531$. Pristupljeno 3. ožujka 2017.

5. Sud EU-a: C-497/10 PPU, Mercredi v. Chaffea, [2010] ECR I-14309 od 22. prosinca 2010. Dostupna na: URL= http://curia.europa.eu/juris/document/document.jsf? text=\&docid=83470\&pageIndex=0\&doclang=en\&mode=lst\&dir=\&occ=first\&part=1\&cid=814531. Pristupljeno 3. ožujka 2017.

6. Sud EU-a: C-523/07, A, [2009] ECR I-2805 od 2. travnja 2009. Dostupna na: URL=http://curia. europa.eu/juris/document/document.jsf?text=\&docid=73639\&pageIndex=0\&doclang=EN\&mode $=1$ st $\&$ dir $=\& o c c=$ first\&part $=1 \&$ cid $=814531$. Pristupljeno 3. ožujka 2017.

\section{MREŽNI IZVORI}

1. Nacrt prijedloga Zakona o međunarodnom privatnom pravu, srpanj 2016. URL=https://esavjetovanja. gov.hr/ECon/MainScreen?entityId=4310. Pristupljeno 28. prosinca 2016.

2. Obrazloženje Konačnog prijedloga Obiteljskog zakona iz 2015., Zagreb, rujan 2015. URL=http://www. sabor.hr/konacni-prijedlog-obiteljskog-zakona-drugo-cit0001. Pristupljeno 28. prosinca 2016.

3. Praktični priručnikza primjenu Uredbe Bruxelles II.a, Europska komisija, Bruxelles, 2014. URL=http:// ec.europa.eu/justice/civil/files/brussels-ii-practice-guide-hr.pdf. Pristupljeno 25. studenoga 2016.

4. Proposal for a Council Regulation on jurisdiction, the recognition and enforcement of decision in matrimonial matters and the matters of parental responsibility, and on international child abduction (recast), $\operatorname{COM(2016)} 411$ final, European Commission, Brussels, 30. lipnja 2016. URL=https://ec.europa. eu/transparency/regdoc/rep/1/ 2016/EN/1-2016-411-EN-F1-1.PDF. Pristupljeno 21. studenoga 2016.

5. Study on the assessment of the Regulation (EC) No 2201/2003 and the policy options for its amendment; Final report; Analytical Annexes, European Commission, Directorate-General for Justice and Consumers, Brussels, May 2015. URL=http://ec.europa.eu/justice/civil/files/bxl-iia-final-report-analtical-annexes.pdf. Pristupljeno 15. prosinca 2016.

6. Study on the assessment of the Regulation (EC) No 2201/2003 and the policy options for its amendment; Final report; Evaluation, European Commission, Directorate-General for Justice and Consumers, Brussels, May 2015, URL=http://ec.europa.eu/justice/civil/files/bxl-iia-final-report-evaluation. pdf. Pristupljeno 15. prosinca 2016.

7. Uredba Vijeća (EZ) broj 2201/2003 o nadležnosti i priznanju i ovrsi odluka u bračnim predmetima i predmetima roditeljske odgovornosti, kojom se ukida Uredba (EZ) broj 1347/2000, URL=http:// eur-lex.europa.eu/legal-content/HR/TXT/?uri=celex\%3A32 003R2201. Pristupljeno 21. studenoga 2016. 
Slađana Aras Kramar*

\section{MARGINALIA TO THE (INTERNATIONAL) JURISDICTION IN THE MATTERS OF PARENTAL RESPONSIBILITY**}

\section{Summary}

The criteria of the Council Regulation (EC) No 2201/2003 of 27 November 2003 concerning jurisdiction and the recognition and enforcement of judgments in matrimonial matters and the matters of parental responsibility, repealing Regulation (EC) No 1347/2000 (hereinafter: Regulation) concerning the jurisdiction in the matters of parental responsibility differ from the criteria adopted in domestic law. First, this applies to situations in which the ancillary matters relating to parental responsibility are connected with the divorce proceedings. The specificities of these proceedings of domestic law are also peaceful resolution mechanisms. The peaceful resolution mechanisms should precede the seising of a court, which opens the question of the definition of "seising of a court" in the system of the jurisdiction established by the Regulation.

The aim of this paper is to analyse the rules of the (international) jurisdiction for the ancillary proceedings on parental responsibility. The practical issues that arise from the implementation of the Regulation are also discussed. At the time of writing, the Proposal for a recast of the Regulation was published, in which certain interventions in the system of jurisdiction in the matters of parental responsibility are made. The procedural consequences of the revised rules on jurisdiction in the matters of parental responsibility are also analysed in this paper.

Keywords: $\quad$ (Ancillary) dispute on parental responsibility, jurisdiction, peaceful dispute resolution, Brussels Regulation II bis, procedure

\footnotetext{
* Slađana Aras Kramar, PhD, Assistant Professor, Department of Civil Procedural Law, Faculty of Law, University of Zagreb. Trg maršala Tita 14, 10000 Zagreb, Republic of Croatia. E-mail address: saras@pravo.hr.

** This work is co-financed by Croatian Science Foundation, project no. 6988.
} 